Vol. 15, n² | 2011

Varia

\title{
Questions that Remain: Pieter Spierenburg's reply to Randolph Roth
}

\section{Pieter Spierenburg}

\section{(2) OpenEdition \\ 1 Journals}

Electronic version

URL: https://journals.openedition.org/chs/1297

DOI: $10.4000 /$ chs. 1297

ISSN: 1663-4837

\section{Publisher}

Librairie Droz

\section{Printed version}

Date of publication: 1 December 2011

Number of pages: 147-150

ISSN: 1422-0857

\section{Electronic reference}

Pieter Spierenburg, "Questions that Remain: Pieter Spierenburg's reply to Randolph Roth", Crime, Histoire \& Sociétés / Crime, History \& Societies [Online], Vol. 15, n² | 2011, Online since 01 December 2014, connection on 23 March 2022. URL: http://journals.openedition.org/chs/1297 ; DOI: https:// doi.org/10.4000/chs. 1297 


\title{
Questions that Remain
}

\author{
Pieter Spierenburg's reply to Randolph Roth
}

On 15 June 2011, the day on which I read Randolph Roth's reply to my critical review, the Volkskrant published an item about an exhibition in a Leiden museum occasioned by the fact that in the Netherlands very few of the nineteen Dutchmen who had received the Nobel prize had a street named after them ${ }^{1}$. It is surely to Roth's credit that he leads my thoughts into unexpected directions from where they would have stayed away without his book. The heading in the Volkskrant simply states: «the Dutch don't care about the Nobel prize», but could there be a link between this lack of street names and Dutch homicide rates? If we assume a delay of some ten years between receiving the prize and an occasion for the naming of a street or square after the laureate, quite a number of the implicit omissions occurred in the 1920s and 1930s, when Dutch homicide rates were exceptionally low. But then again, perhaps Nobel laureates do not count as national heroes.

Roth calls my defense of Norbert Elias' theory of civilizing processes (depreciatingly referred to as «the civilization thesis ») aggressive. Maybe that is a pun on the subject under discussion. In line with this perception, however, he constantly attributes «claims» and «objections» to me and even has me see «grave threats ». To the contrary, I am quite willing to accept all the evidence of American Homicide - if my doubts are addressed - and assess its meaning for the theory of civilizing processes. Indeed, I am grateful to Roth for his attempt, at the end of his reply, to make a beginning with such an assessment. I had merely put a few questions, occasioned by the fact that some vital information was so hard to find in his book and even on his website. His reply does not satisfactorily answer all my questions.

Let me first clarify a number of misunderstandings (at the risk of being superfluous, because many readers of our exchange will already have concluded this). I present my points more or less in the order in which these misunderstandings manifest themselves in Roth's reply. (1) I did not call the thesis of American Homicide an extension of LaFree's thesis. I used the word parallel and concluded that it reads like an extension. In my review I quoted the full passage that Roth repeats in his reply. I had read on Roth's website that he had developed his ideas independently from LaFree and I do not particularly care about this issue. (2) I do not prefer only «total homicide rates.» In fact, I have amply analyzed, quantitatively and even more so qualitatively, various types of homicide in my History of Murder (2008). I fail to see why we can't do both: present total figures and figures per type of homicide.

There were no female Dutch Nobel Laureates. It should be noted that the delay between my review and Randy's reply was not at all his fault. It resulted from the fact that this Forum issue had originally been planned as an exchange between more than two scholars. 
Moreover, for many periods and places it is impossible or difficult to distinguish between types of murders. We do know that, whenever and wherever homicide rates are very high, male-on-male fighting largely accounts for this.

(3) Roth says that I question his «decision to include political homicides and law enforcement homicides » in his study. I have said nothing about political homicides. By law enforcement homicides he presumably means killings by police: as already explained, these are acts of state violence, hence not homicides. (4) I am puzzled why Roth should think that I object to the capture-recapture method, which I called refined. I merely said that this method cannot be applied for much of European history. Dutch newspapers of the seventeenth and eighteenth centuries, for example, report about such matters as incoming ships, but almost never about murder. (5) In connection with this, Roth states that I consider the distinction between legal and non-legal sources arbitrary. I had merely asked him to indicate exactly, within the legal category, for which times and places this category included coroner's records and for which periods and places indictments only - a piece of information that was very hard to find. If I understand his reply correctly, I have to look this up on his website for each case separately. That is an unreasonable demand from even the interested reader.

The last misunderstanding (6) concerns, not so much my review, but Elias' theory as a whole. Roth refers to this theory in terms of causes and consequences, whereas Elias maintains that in order to explain historical transformations we need to clarify the structure of processual change. Historical transformations are made up of interdependent long-term processes that mutually affect each other. Processes of state formation and nation building, for example, are usually interrelated, whereas Roth wants to rigorously separate them.

Next, I want to briefly identify the remaining problems or the questions that, in my view, have not been satisfactorily answered. These are the following:

1. Colonial rates. Are there years during the colonial era for which the legal records consist of indictments only, combined with the non-availability of newspapers (so that application of the capture-recapture method is impossible)? If so, which years and for which regions? This is simply a piece of information that should have been provided in the book. I maintain that homicide rates based on prosecution records alone are worthless. In sixteenth-century Amsterdam, for example, the ratio of detected to prosecuted killings was $9: 1^{2}$.

2. Colonial violence. Even if all rates presented by Roth are reliable, the remarks in my review are pertinent: can we consider the colonies as nonviolent societies?

3. The so-called age-specific homicide rates. What prevents him from first presenting total homicide rates and then examining contributing factors such as the proportion of children in a population, if known? That procedure contributes to historical comparability. Moreover, in which category do we place cases in which an adult kills an unrelated youth? Is this not an indication for the level of

Pieter Spierenburg, Long-Term Trends in Homicide. Theoretical Reflections and Dutch Evidence, Fifteenth to Twentieth Centuries, in Eric A.Johnson \& Eric H. Monkkonen (Eds), The Civilization of Crime. Violence in Town and Country since the Middle Ages, Urbana, Chicago, University of Illinois Press, 1996, pp. 63-105 (in particular p. 79). 
aggression among adults? The criterion of population at risk is only one among others. The homicide rate also tells us something about how familiar, or not familiar, people of all ages were with murder in their community. Finally, the category of homicide among unrelated adults is far from homogeneous. It includes both the conventional bar room brawl and the liquidation of a competitor in organized crime.

4. The obligation to disaggregate. I noted that, due to the great regional and temporal variations in the feelings of communalism that are supposed to determine the homicide level, Roth's theory obliges him constantly to disaggregate. That seems to me a problem inherent in the theory.

5. Small populations. That the size of the population should not be too small has already been posited by Lawrence Stone and this continues to be a sound principle, despite Roth's sophisticated mathematics ${ }^{3}$. I do consider Robert Dykstra too radical in this. In the small Swedish town of Arboga, for example, the fluctuations of the homicide rate per decade are meaningless, but the average rate of 23 between 1452 and 1543 is meaningful ${ }^{4}$. However, when homicide rates in small counties are expected each time to reflect phases of conflict or solidarity extending over just a few years, this expectation prohibits us from averaging them over a longer period.

6. The role of honor. Honor is obviously related to status, culture and much more. The idea that traditional male honor based on bravery and violence migrated from antebellum Southern whites to postbellum Southern blacks and with them to the inner cities of the North is widespread in historiography. It was first put forward by Edward Ayers and popularized by authors such as Fox Butterfield ${ }^{5}$. My modest contribution was to connect the honor-violence syndrome to the American path of state formation. Roth believes that he can identify some killings as killings over honor while others are not. By contrast, most historians of early modern Europe point out that this is a fallacy and that honor is involved in nearly all cases of male-on-male violence, for example conflicts over property rights $^{6}$.

Let me finish on a theoretical note. Obviously there is a distinction between examining long-term developments and short-term or middle-term fluctuations. Whereas Elias' theory is primarily concerned with the former, Roth's thesis appears more attuned to the latter. We already knew that the long-term development on the North-American continent was a bit fuzzy compared to that in Europe. With respect

Lawrence Stone, Interpersonal violence in English society, 1300-1980, Past and Present, 1983, 101, pp. 22-33.

4 Pieter Spierenburg, Long-term historical trends of homicide in Europe, in William Pridemore and Marieke Liem (eds.), A sourcebook of European homicide, New York, Springer (Forthcoming).

5 Edward L. Ayers, Vengeance and justice. Crime and punishment in the 19th-century American South, New York, Oxford, 1984; Fox Butterfield, All God's children. The Bosket family and the American tradition of violence, New York, 1995.

6 See, for example, Gerd Schwerhoff, Social control of violence, violence as social control. The example of early modern Germany, in Herman Roodenburg \& Pieter Spierenburg (Eds), Social Control in Europe, Vol. 1, 1500-1800. Columbus, Ohio State UP, 2004, pp. 220-246. 
to the European long-term development, in the words of Manuel Eisner, «the evidence is so consistent, the secular decline so regular and the differences in levels so large, that it seems difficult to refute the conclusion of a real and notable decline ${ }^{7}$. What about fluctuations? For America perhaps Roth's thesis holds; the observations by a number of cultural historians whom he cites point in that direction. For Europe, I am less convinced. That homicide rates soared for brief spans of time in revolutionary situations and during and immediately after the world wars is well-known and in line with Elias' theory. I will have to leave the re-examination of other instances mentioned by Roth for a later time. They are all from his book, save for the case of Corsica. Roger Gould's book came to my attention only recently through an article by Anton Blok ${ }^{8}$ and it too deserves a more thorough treatment ${ }^{9}$.

One of the most conspicuous short-term fluctuations in European history concerns the Amsterdam peak in homicides (rising to nearly 10 per 100,000) from the early 1690 s to the mid-1720s, which largely coincided with the heyday of knife fighting. I am still at a loss how to explain it, but in this case, unfortunately, Roth's thesis is not a good candidate. The most divisive factor in Dutch society at the time had to do with the House of Orange. Much of the Prince's support came from the lower orders, while his major opponents were from Holland's patriciate. The homicide peak extended over the last ten years of William III's rule (historians state that, he was king of The Netherlands and Stadholder of England, if not in name, then in reality) and the first half of the second stadholderless age. Actual strife occurred mainly during the transition, in 1702-1703.

So, yes, I think that the debate will continue, at conferences and in other periodicals. And I hope for a fruitful research climate in the future, so that it can be done with new evidence in hand.

\section{Pieter Spierenburg Erasmus University Rotterdam spierenburg@law.eur.nl}

7 Manuel Eisner, Modernization, self-control and lethal violence. The long-term dynamics of European homicide rates in theoretical perspective, British Journal of Criminology, 2001, 41, pp. 618638 (in particular p. 628). See also Manuel Eisner, Long-term historical trends in violent crime, Crime and Justice. A Review of Research, 2003, 30, pp. 83-142.

8 Forthcoming in the new journal $T$ dschrift over Cultuur en Criminaliteit, Fall 2011.

9 Roger V. Gould, Collision of wills. How ambiguity about social rank breeds conflict, Chicago, University of Chicago Press, 2003. Gould apparently based his graph of annual homicide rates in Corsica (p.156) on his own research, but he does not specify his sources. Neither does he discuss possible differences with the rates, calculated as five-year averages, in Stephen Wilson, Feuding, conflict and banditry in 19th-century Corsica, Cambridge, CUP, 1988 (p. 16). For example, Wilson has a rate of 28 for the period 1881-1885, when, according to Gould's graph, the annual rates fluctuated between about 16 and about 25. Wilson's table is from 1816 to 1900 , whereas Gould's graph is from 1825 to 1914. In Wilson's table, the period 1816-1820, with no political upheaval in France, has the second highest homicide rate. 